\title{
THE HYDROID OF THE MEDUSA DIPURENA HALTERATA (FORBES)
}

\author{
By W. J. Rees, M.Sc.
}

Research Assistant at the Plymouth Laboratory

(Text-figs. I-3)

Although the medusa Dipurena halterata (Forbes, I846) is well known, and has been figured by a number of authors (e.g. Forbes, I848; Browne, I897), the hydroid of this peculiar species has remained unknown. This medusa is rather scarce at Plymouth (Russell, 1938). On May 3 I938 I had the good fortune to find at Plymouth a small hydroid of the Syncoryne type which later liberated young medusae, and these proved to be young specimens of Dipurena halterata.

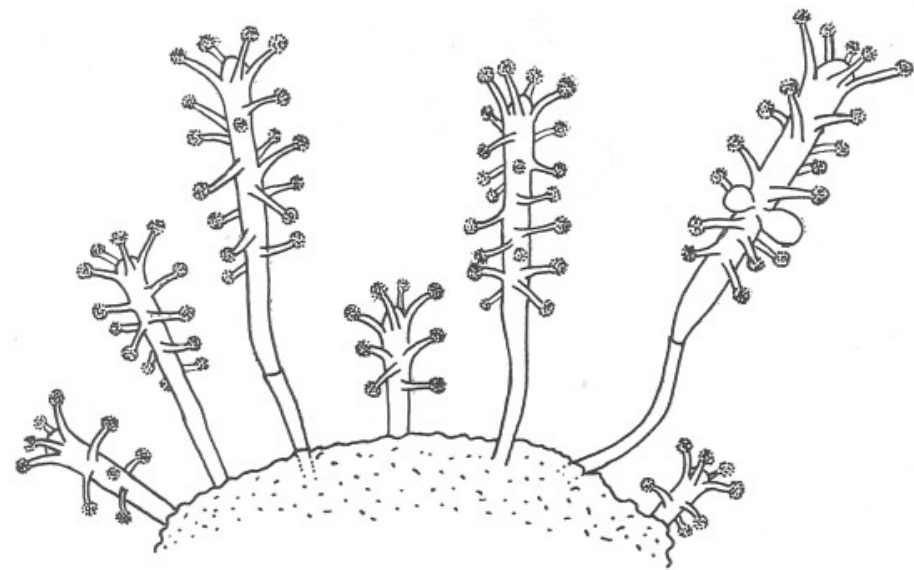

Fig. I. Portion of colony of Dipurena halterata; Plymouth, 4. v. 38.

The hydroid was found growing on and in a sponge, Chalina montagui (Bowerbank), attached to a piece of Lepralia foliacea (Ellis \& Solander), dredged near the Mewstone. Another piece of sponge from the same locality carried a young colony of the hydroid.

THE HYDROID. The colony was small, with a total height rarely exceeding $2.5 \mathrm{~mm}$. (Fig. I). At first sight the polyps appeared to be very similar to those of Zanclea implexa (Alder). The polyps had the brownish or reddish colour common in species of Syncoryne. There were no stolons on the surface of the sponge, but there were many branching stolons deeply buried in the substance of the sponge. In the fully developed polyps the stems, covered 
by a thin non-annulated perisarc, reached a height of $0.5-0.8 \mathrm{~mm}$. above the surface of the sponge. Young polyps on the surface were sessile with no visible hydrocaulus. Hand sections kindly prepared by Mr L. R. Crawshay, who identified the sponge, revealed that the young hydranths began their development deep down in the substance of the sponge and later forced their
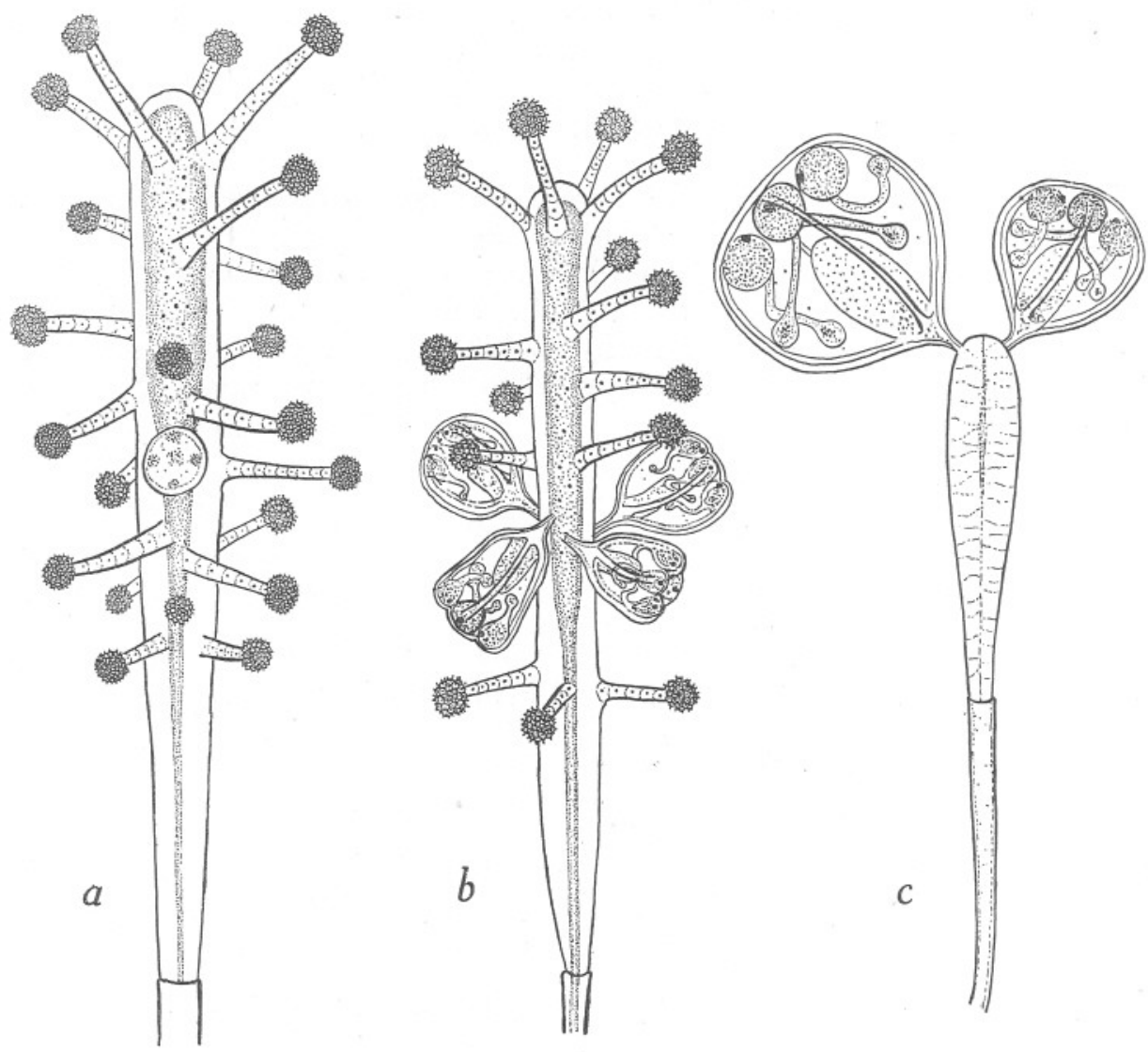

Fig. 2. Dipurena halterata; $a$, fully developed hydranth with a young medusa bud, 5. v. 38 ; $b$, hydranth with four medusa buds, I2. v. 38 ; $c$, hydranth reduced to a blastostyle, I8. v. 38; all from Plymouth.

way to the surface. These buried rudimentary polyps possessed short tentacles with capitate heads which later, on reaching the surface, developed into typical tentacles. The sponge itself appeared to be in an emaciated condition, but whether this was due to the presence of the hydroid was impossible to determine because of the lack of adequate material. A detailed study of this association might prove well worth while.

The fully developed hydranths were $\mathrm{I} \cdot \mathrm{O}-\mathrm{I} \cdot 7 \mathrm{~mm}$. in length with a diameter 
of $0.14-0.15 \mathrm{~mm}$. The tentacles were all capitate, $17-24$ in number. The distal end of the hydranths had four or five tentacles more or less in a whorl around the mouth. The other tentacles were irregularly scattered over the anterior and middle parts of the hydranth while the posterior part carried no tentacles (Fig. 2a). These tentacles were longer than the diameter of the hydranth and had capitate heads $0.06-0.08 \mathrm{~mm}$. in diameter.

Medusa buds were borne on the hydranth a little behind the middle region of the body (Fig. 2b). Fully developed buds were covered by a thin transparent

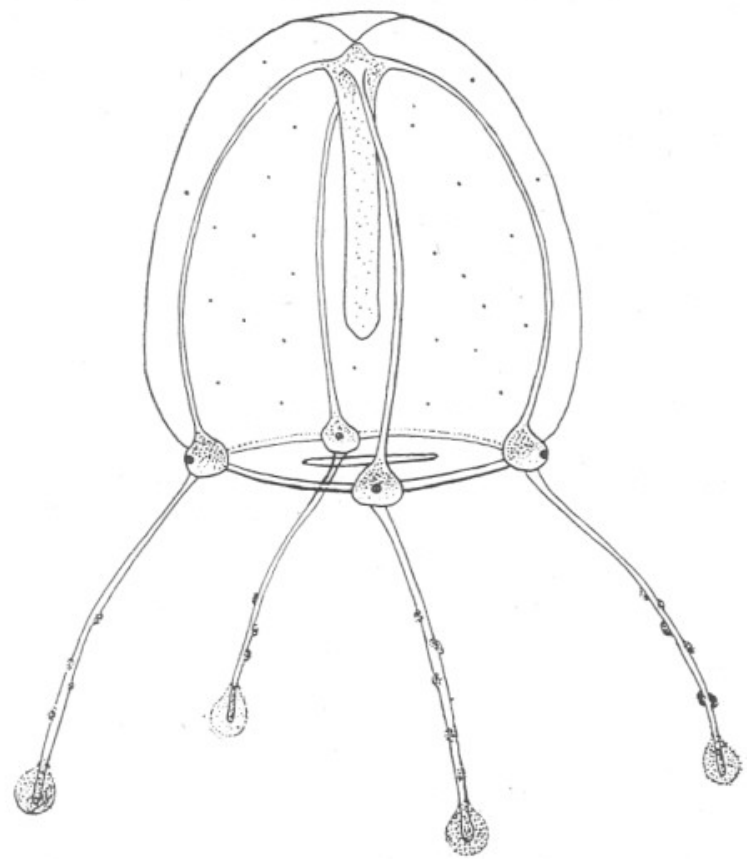

Fig. 3. Newly liberated medusa of Dipurena halterata obtained from the hydroid; Plymouth, 6. v. 38.

perisarc and were $0.40-0.45 \mathrm{~mm}$. in diameter. A single hydranth had one to three medusa buds on it at the same time. These medusa-bearing hydranths usually became reduced to blastostyles devoid of tentacles (Fig. 2c).

The Medusa. The newly liberated medusa was bell-shaped, a little higher than wide, with a height of $\mathrm{I}^{\cdot} 5^{-\mathrm{I}} \cdot 6 \mathrm{~mm}$. and a diameter of $\mathrm{I} \cdot 3-\mathrm{I} \cdot 4 \mathrm{~mm}$. (Fig. 3). The umbrella had a fairly thin jelly with a few scattered nematocysts on its exumbrellar surface. The velum was broad. The stomach was cylindrical, reaching to about two-thirds of the height of the subumbrellar cavity. The mouth was simple without lips. The radial canals and ring canal were very narrow. There were four perradial tentacles arising from distinct bulbs each with a prominent black ocellus. The ends of the tentacles were swollen to form distinct knobs armed with batteries of nematocysts. The distal half of 
the tentacles also carried small irregularly placed batteries of nematocysts. The colour of the manubrium was a pale green, while the tentacle bulbs and the endoderm of the capitate ends of the tentacles were brick red in colour. At this stage there was no green colour in the tentacle bulbs, it appeared later, however, in the specimens which I reared.

One reared specimen reached a bell height of $2.8 \mathrm{~mm}$. and a diameter of $2.5 \mathrm{~mm}$. At this stage the linear swellings on the radial canals had developed. These were regarded by Forbes (1848) as ovaries, but it has since been shown by Haeckel (1879) and Browne (1897) that the gonads develop on the manubrium. The exact nature of these swellings is still unknown. Similar swellings have been observed by Russell \& Rees (1936) on the radial canals of Zanclea. The terminal knobs on the tentacles were now much bigger than in the newly liberated medusa and had a diameter of $0.16-0.22 \mathrm{~mm}$. The irregularly placed batteries of nematocysts of the young medusa were now developing into complete rings of nematocysts. The best developed tentacle possessed three complete rings and one incomplete ring of nematocysts as well as the terminal knob.

During July and August 1938 I collected many specimens of Dipurena halterata in various stages of development from the plankton at Valentia Harbour, Co. Kerry. A comparison of the young stages from Valentia with those reared from the hydroid at Plymouth confirms earlier observations made in this paper that the hydroid and its young medusa are stages in the life history of $D$. halterata.

Although the hydroid is of the Syncoryne type it cannot be referred to Syncoryne because the characters of the medusa alone are sufficient to warrant the generic distinction of the species from Syncoryne. It is therefore proposed to retain the name Dipurena halterata for both hydroid and medusa.

I am indebted to the Royal Society for a grant to cover my expenses at Valentia Island.

\section{REFERENCES}

Forbes, Edward, I848. A Monograph of the British Naked-eye Medusae, pp. I-Io4. Ray Society.

Browne, E. T., I897. On British medusae. Proc. Zool. Soc. London, pp. 816-35.

HAeCKel, ERnst, I879. Das System der Medusen, pp. I-672.

Russell, F. S., I938. The Plymouth offshore medusa fauna. Fourn. Mar. Biol. Assoc., Vol. XXII, pp. 4II-40.

Russell, F. S. \& REES, W. J., 1936. On rearing the hydroid Zanclea implexa (Alder) and its medusa Zanclea gemmosa McCrady, with a review of the genus Zanclea. fourn. Mar. Biol. Assoc., Vol. xxi, pp. 107-29. 